\title{
Produksi Rumput Tebu Salah (Phragmites Sp) sebagai Sumber Hijauan Pakan Potensial pada Berbagai Umur Pemotongan
}

\author{
Production of "Tebu Salah" Grass (Phragmites Sp) As A Potential Source of Forage \\ at Different Cutting Ages (Harvesting). \\ Irma Badarina \\ Jurusan Peternakan Fakultas Pertanian Universitas Bengkulu \\ Jalan Raya Kandang Limun Bengkulu Telp. (0736) 21170 Pst 219.
}

\begin{abstract}
The aim of this research was to evaluate the production of tebu salah grass as a potential source of forage at different cutting ages (harvesting). The research was conducted in laboratory of nutrition of animal science department, agriculture faculty, University of Bengkulu and at swamp area of kelawi riverside Rawa Makmur, Bengkulu. Randomized completely design was used with five treatments and three replications. The treatments were different cutting ages of 2, 4, 6, 8, and 10 weeks after the uniformity with the cutting height of 30 centimeters from the ground. The result showed that the older the cutting age, the higher the fresh and dry matter production. The cutting age of 10 weeks (P5 treatment) showed the highest dry matter production. The stems fraction at 10 weeks of harvesting (P5) contributed the highest portion of the total dry matter production. In conclusion, the tebu salah plants experienced a changing in plant proportion part following the cutting age.
\end{abstract}

Key words: Phragmites sp, production, forage, cutting age

\begin{abstract}
ABSTRAK
Penelitian ini bertujuan untuk mengkaji produksi rumput tebu salah (Phragmites sp) sebagai sumber hiajauan pakan potensial pada berbagai umur pemotongan. Penelitian dilaksanakan di lahan rawa pinggir sungai Kelawi Rawa Makmur Kodya Bengkulu dan Laboratorium Peternakan Jurusan Peternakan Fakultas Pertaniana Unib. Penelitian menggumakan Rancangan Acak Lengkap dengan lima perlakuan dan tiga ulangan. Perlakuan yang diberikan adalah umur pemotongan 2, 4, 6, 8, dan 10 minggu setelah penyeragaman dengan melakukan pemotongan setinggi $30 \mathrm{~cm}$ di atas permukaan tanah. Hasil penelitian menunjukkan bahwa interval pemotongan berpengaruh nyata meningkatkan produksi berat segar dan bahan kering rumput tebu salah. Panen tertinggi diperoleh pada umur pemanenan 10 minggu (P5). Fraksi batang pada umur pemanenan 10 minggu (P5) menyumbang bagian terbesar dari total produksi bahan kering. Hal ini berarti terjadi perubahan dalam proporsi bagian tanaman seiring dengan bertambahnya umur tanaman.
\end{abstract}

Kata Kunci: Phragmites sp, produksi, hijauan, umur potong

\section{PENDAHULUAN}

Hijauan merupakan pakan utama ternak ruminansia, oleh karena itu penyediaan hijauan pakan merupakan faktor penting yang dapat menunjang keberhasilan peternakan ruminansia.

Ketersediaan hijauan pakan di daerah sangat bergantung dari fluktuasi hujan dimana melimpahnya pada musim hujan produksinya melimpah sebaliknya pada musim kemarau produksinya sedikit. Masalah lain yang dihadapi dalam penyediaan pakan adalah ketersediaan lahan yang terbatas khusus untuk menanam rumput unggul, karena lahan diprioritaskan untuk tanaman pangan.

Pemanfaatan rumput liar yang banyak tersedia di sekitar kita merupakan salah satu alternative untuk mengatasi masalah di atas. Salah satu rumput liar yang tumbuh dengan baik yang belum dimanfaatkan adalah rumput tebu salah (Phragmites sp). Rumput ini banyak dijumpai di daerah rawa dan tepian sungai yang banyak terdapat di daerah Bengkulu. 
Skerman dan Riveros (1990) menyatakan rumput tebu salah (Phragmites sp) penyebarannya melalui pertumbuhan sistem akar yang agresif dan stolon. Suhu untuk tumbuh berkisar antara $30-35^{\circ} \mathrm{C}$, tumbuh di daerah perairan, tahan terhadap genangan air, tumbuh subur pada curah hujan 200-500 mm, hidup pada ketinggian 1-1.700 m dpl. Ditinjau dari segi nutrisi, rumput yang cukup unggul dengan kandungan bahan organik : $88,35 \%$, PK $=13,59 \%$ dan SK $=29,01 \%$ (hasil analisis) dibandingkan dengan rumput gajah (Pennisetum purpureum) dengan kandungan $\mathrm{BO}$ : 84,3\%, PK $=11,4 \%$ dan $\mathrm{SK}=29,5 \%$ (Tiilman et al., 1991). Dengan melihat potensi ketersediaannya yang cukup banyak dan selalu tersedia sepanjang tahun serta nilai gizinya yang cukup baik, maka rumput tebu salah diharapkan dan dapat dimanfaatkan sebagai sumber hijauan pakan alternative terutama pada musim kemarau.

Hasil penelitian Badarina et al. (2005) didapatkan bahwa pemanfaatan $100 \%$ rumput tebu salah sebagai ransum basal pada ternak domba mencukupi kebutuhan energi tercerna untuk hidup pokok sebesar 2,88 Mkal melebihi standar yaitu sebesar 2,59 Mkal (Kearl, 1982). Selain itu nilai PBB yang dicapai sebesar 100 gram/hari. Dengan demikian dapat dikatakan bahwa pemberian tebu salah sebagai pakan basal dapat dijadikan alternative sumber hijauan yang cukup baik.

Pemanfaatan tebu salah pada penelitian di atas dipanen tanpa memperhatikan umur potong atau kedewasaan tanaman. Menurut Coleman dan Henry (2002) kedewasaan, variasi dalam genetik, manajemen pemeliharaan dan lingkungan Sangay mempengaruhi koalitas atau nilai nutrisi hijauan dan juga produksi tanaman. Kedewasaan (umur) tanaman mempunyai peranan terbesar dalam menentukan koalitas hijauan dan produksi tanaman (Millar, 1984).

Berbagai metode telah dikembangkan untuk menentukan kualitas hijauan pakan baik secara fisik, kimia dan biologis. Masing-masing memiliki kelebihan dan kekurangan. Metode yang terbaik adalah dengan tolok ukur performans ternak (biologis). Metode kimia (analisis kimia) dapat menyediakan informasi tentang komposisi kimia hijauan yang mempengaruhi kecernaan. Fraksi serat dari suatu bahan makanan memiliki pengaruh terbesar terhadap kecernaan (Mc. Donald $d k k$., 1981).
Komponen serat pakan masing-masing dapat diestimasi dengan sejumlah prosedur ekstraksi. Van soest (1982) membagi hijauan menjadi dua fraksi berdasarkan kelarutannya dalam deterjen yaitu : isi sel (Neutral detergent solubles/NDS) dan dinding sel (Acid Detergent Fiber). Analisa Van Soest mempunyai keunggulan terutama dalam hal eratnya hubungan antara ADF (fraksi yang tidak larut dalam deterjen asam) dan ADL (Acid Deterjen Lignin) dengan manfaat bahan makanan bagi ternak.

Berlatar belakang hal tersebut di atas, maka perlu diketahui perubahan hasil produksi pada berbagai umur pemotongan. Diharapkan hasil penelitian ini akan dapat memberikan informasi tentang umur yang tepat untuk memanfaatkan rumput tebu salah sebagai sumber hijauan pakan potensial.

\section{MATERI DAN METODE}

Penelitian dilalksanakan di Laboratorium Makanan Ternak Jurusan Peternakan Faperta Unib dan lahan rawa di pinggir Sungai Kelawi Rawa Makmur Kodya Bengkulu selama kurang lebih 8 bulan.

Luas lahan yang digunakan untuk penelitian adalah $10 \times 15 \mathrm{~m}^{2}$ dengan luas petak satu unit percobaan $6 \mathrm{~m}^{2}$. Bahan rumput tebu salah berupa rumput yang sudah tumbuh secara alami di lapangan. Penyeragaman dilakukan dengan melakukan pemotongan setinggi $30 \mathrm{~cm}$ di atas permukaan tanah, selanjutnya dilakukan dengan perlakuan umur pemotongan.

Penelitian menggunakan Rancangan Acak Lengkap dengan lima perlakuan dan diulang sebanyak tiga kali. Perlakuan yang diberikan adalah umur pemotongan selama 2, 4, 6, 8 dan 10 minggu setelah penyeragaman. Peubah yang diamati adalah produksi bahan segar dan bahan kering. Data yang diperoleh dianalisis varian (ANOVA) dan unutk uji lanjut menggunakan uji DMRT (Steel dan Torrie, 1989).

\section{HASIL DAN PEMBAHASAN}

Hasil panen rumput tebu salah diukur dalam keadaan segar (produksi bahan segar) dan dalam keadaan kering (produksi bahan kering). Hasil panen menunjukkan adanya peningkatan secara significant seiring dengan makin meningkatnya umur pemotongan. 


\begin{tabular}{|c|c|c|c|c|c|}
\hline \multirow{2}{*}{ Perlakuan } & \multicolumn{3}{|c|}{ Ulangan (gram) } & \multirow{2}{*}{ Total } & \multirow{2}{*}{ Rata-rata } \\
\hline & 1 & 2 & 3 & & \\
\hline 1 & 406 & 345 & 328 & 1079 & $359,6667 a$ \\
\hline 2 & 2167 & 1272 & 1808 & 5247 & $1749 b$ \\
\hline 3 & 2510 & 2181 & 1880 & 6571 & $2190,3333 b$ \\
\hline 4 & 3265 & 2779 & 3615 & 9659 & $3219,6667 \mathrm{c}$ \\
\hline 5 & 4076 & 3680 & 4320 & 12076 & $4025,333 d$ \\
\hline
\end{tabular}

Huruf yang berbeda pada kolom yang sama menunjukkan perbedaan nyata $(\mathrm{P}<0,05)$

Tabel 2. Produksi Bahan Kering Rumput Tebu Salah

\begin{tabular}{cccccc}
\hline \multirow{2}{*}{ Perlakuan } & \multicolumn{3}{c}{ Ulangan (gram) } & \multirow{2}{*}{ Total } & \multirow{2}{*}{ Rata-rata } \\
\cline { 2 - 4 } 1 & 213,9726 & 197,8744 & 195,3654 & 607,2124 & $202,4041 \mathrm{a}$ \\
\cline { 2 - 4 } 2 & 607,0404 & 369,3563 & 486,5963 & 1462,993 & $487,6643 \mathrm{~b}$ \\
3 & 601,3977 & 514,7382 & 483,0776 & 1599,2135 & $533,0712 \mathrm{~b}$ \\
5 & 956,0631 & 972,5299 & 1025,8115 & 2954,4045 & $984,8015 \mathrm{c}$ \\
\hline
\end{tabular}

Huruf yang berbeda pada kolom yang sama menunjukkan perbedaan nyata $(\mathrm{P}<0,05)$

Panen tertinggi diperoleh pada umur pemotongan 10 minggu setelah penyeragamn (P5). Hal ini berarti sampai umur tanaman 10 minggu (2,5 bulan). Pertumbuhan tanaman masih kearah perkembangan vegetatif dimana pertumbuhan batang dan daun masih banyak terjadi. Perlakuan P2 dan P3 menunjukkan tidak terdapat perbedaan yang nyata terhadap produksi rumput, artinya panen pada minggu ke 6 (P3) tidak terdapat peningkatan hasil yang nyata terhadap produksi rumput, artinya panen pada minggu ke 6 (P3) tidak terdapat peningkatan hasil yang nyata dibanding meinggu ke empat (P2). Keadaan ini diduga karena pada minggu ke tiga setelah penyeragaman terjadi tsunami kecil karena gempa bumi skala 7,9 ritchter di Bengkulu (tanggal 12 Septembet 2007). Lokasi penelitian yang hanya berjarak 30 meter dari pinggir pantai menyebabkan air laut menggenangi lahan penelitian. Rumpu tebu salah menjadi stress karena tanah menjadi kelebihan garam asal air laut.

Interval pemotongan berpengaruh nyata meningkatkan produksi hijauan. Hasil penelitian yang diperoleh pada penelitian ini sama dengan beberapa penelitian mengenai interval pemotongan pada beberapa penelitian jenis hijauan (Mansyur dkk., 2005 : Rahman, 2001 : Devitriano, 2001).

Tabel 3. Produksi Bahan Kering Rumput Bagian Batang dan Daun

\begin{tabular}{ccc}
\hline Perlakuan & Batang & Daun \\
\hline 1 & $101,9043 \mathrm{a}$ & $100,4999 \mathrm{a}$ \\
2 & $228,3224 \mathrm{a}$ & $259,3419 \mathrm{~b}$ \\
3 & $265,6816 \mathrm{~b}$ & $267,3896 \mathrm{~b}$ \\
4 & $502,7522 \mathrm{~b}$ & $482,0493 \mathrm{c}$ \\
5 & $1121,0459 \mathrm{c}$ & $656,9048 \mathrm{~d}$ \\
\hline
\end{tabular}

Huruf yang berbeda pada kolom yang sama menunjukkan perbedaan nyata $(\mathrm{P}<0,05)$ 

Produksi total rumput tebu salah merupakan penjumlahan dari produksi bagian batang dan daun dari rumput tebu salah. Pada Tabel 3. dapat dilihat bahwa terdapat peningkatan yang nyata hasil panen dengan meningkatnya umur pemotongan dari fraksi batang dan daun. Hasil penelitian ini menunjukkan bahwa pada umur pemanenan 10 minggu (P5) fraksi batang menyumbang $63,0525 \%$ dari total produksi bahan kering, sedangkan fraksi daun 36,9475\%. Hal ini memberikan indikasi bahwa terjadi perubahan dalam proporsi bagian tanaman seiring dengan bertambahnya umur/kedewasaan tanaman. Terjadinya penurunan perbandingan daun dan batang telah dimulai pada umur pemanenan 8 minggu (P4).

Perubahan komposisi fraksi daun dan batang akan mempengaruhi komposisi kimia tanaman yang pada akhirnya akan mempengaruhi nilai nutrisi dari tanaman. Batang mempunyai kandungan serat yang lebih tinggi dibanding dengan daun karena banyak mengandung karbohidrat struktural dan jaringan penunjang. Sedangkan daun mengandung sebagian besar sel mesofil dengan dinding yang tipis (Buxton dan Redfearn, 1997). Dengan demikian dari hasil penelitian ini pemanenan setelah umur 10 minggu nampaknya akan berdampak terhadap penurunan kecernaan pakan karena terjadi penuruanan kualira pakan. Van Soest (1994) menyatakan serat kasar diduga kaya akan lignin dan selulosa sehingga sulit dicerna.

\section{SIMPULAN}

Interval pemotongan berpengaruh nyata meningkatkan produksi berat segar dan bahan kering hijauan rumput tbu salah. Hasil panen tertinggi diperoleh pada umur pemotongan 10 minggu (P5). Fraksi batang pada umur 10 minggu (P5) menyumbang bagian terbesar dari total produksi bahan kering (63,0525\%). Hal ini berarti terjadi perubahan dalam proporsi bagian tanaman seiring dengan bertambahnya umur tanaman yang telah dimulai pada umur 8 minggu

Produksi tertinggi diperoleh pada umur pemotongan 10 minggu (P5) sehingga pemanenan disarankan pada umur 10 minggu.

\section{DAFTAR PUSTAKA}

Badarina, I., T. Akbarillah, Hidayat, M. Astuti dan S. Wahyudi. 2005. Nilai Total Zat Nutrisi Tercerna, Kecernaan Energi dan Performans Produksi Domba Lokal Jantan ynah Diberi Ransum Berbasis Rumput Tebu Salah (Phragmites Sp.) sebagai Sumber Hijauan Pakan Alternatif. J. Ilmiah Ilmu-ilmu Peternakan. Edisi Khusus. Volume VIII. Desember 2005.

Buxton, R. D. And D. R. Redfearn. 1997. Plant Limitation to Fiber Digestion and Utilization. J. Nut. Supp. : 814-818.

Colemen, S. W. and D. A. Henry, 2002. Nutritive Value of Herbage in M. Freer and H. Dove. Sheep Nutrition. CAB International. Wallingford. UK. 1-26.

Devitriano, D. 2001. Pengaruh Pemupukan Nitrogen dan Interval Pemotongan terhadap Pertumbuhan dan Perkembangan Rumput Lokal Kumpai (Hymenache amplexicaulis R. Nees). J. Ilmiah Ilmu-Ilmu Peternakan. 4 : 21-220.

Jung, H. G. and M. S. Allen. 1995. Characteristic of Plant Cell Wall Affecting Intake and Digestibiloity of Forages by Ruminant. J. Anim. Sci. 73 : 2774-2970.

Mansyur, L. Abdullah, H. Djuned, T. Dhalika. 2005. Perubahan dalam Hasil Panen dan Kandungan Fraksi Serat pada Tingkat Umur Pemotongan Rumput Setaria (Setaria sphacelata schum). J. Ilmiah IlmuIlmu Peternakan. Volume VIII : 29-36.

Miller. D. A. 1984. Forage Crops. Mc. GrawHill. Inc. New York.

Mc. Illory, R. J. 1977. Pengantar Budidaya Padang Rumput Tropika. Pradya Paramita Jakarta. 
Mc. Donald, R., R. A. Edwards and J. F. D. Greenhalg. 1981. Animal Nutrition. Longman Inc. New York.

Rahman, S. 2001. Introduksi Tanaman Makanan Ternak di Lahan Perkebunan : respon Beberapa Jenis Tanaman Makanan Ternak terhadap Naungan dan Tata Laksana Pemotongan. J. Ilmiah Ilmu-Ilmu Peternakan 4(1) : 46-53.

Skerman, P. J and Riveros. 1990. Tropical Grasses. FAO. United States, USA.

Steel, R. G. D and Torrie. 1989. Principles and Procedure of Statistics. $2^{\text {nd }}$ Ed. Mc. Graw Hill Book Co. Inc. New York.

Tillman, A. D., S. Reksohadiprodjo, S. Prawirokusumo dan Lebdo Soekojo. 1991. Ilmu Makanan Ternak Dasar. Gadjah Mada University Press Yogyakarta.

Van Soest, P. J. 1994. Nutritional Ecology of The Ruminant. Cornell University Press, Ithaca, New York, 476 pp.

Wardrop, A. D. 1971. Occurrence and Formation in Plants. In : Lignin Occurance Formation Structure and Reaction. Ed. By Sarkanen and Ludwig. Jhon Wiley and Sons Inc. New York, Londin, Sydney, Toronto.

Whiteman, P. C. 1980. Tropical Pasture Science. University of Queensland. Australia. Oxford University Press New York. 